\title{
Development of Daycare Center for Senior Users as Community-Cohesive Facility
}

\author{
Jeong-Won Han $^{1^{*}}$ \\ ${ }^{1}$ Dept. of Aging and Social Work, Catholic University of Pusan \\ 노인데이케어센터의 지역융합형 발전방향 \\ 한정원 ${ }^{*}$ \\ ${ }^{1}$ 부산가톨릭대학교 노인복지보건학과
}

\begin{abstract}
Facing aged society, long-term care insurance for senior citizen has been introduced in Korea since 2008 in order to take away care burden from family. Daycare Center is one of the institutions developed by the idea of social care. Noticing many problems around adult day services (ADS) such as low quality of services and lack of running sources, this paper would suggest the norm of day care center in terms of community cohesive facilities. In addition, to find out the future vision of ADS, interviews with 10 experts are also analyzed. The result is that new health care program would be community-friendly, tailor-made, communication-based and intergenerational one.

요 약 고령화시대를 맞아서 한국은 2008년부터 노인장기요양보험을 실시하면서 노인부양부담을 가족으로부터 국가 의 책임으로 인식하기 시작하였다. 데이케어센터(주간보호센터)는 사회적 보살핌을 제공하는 시설 중의 하나로 입소생 활시설과는 다른 주간이용시설인데 설립초기 자원부족 및 서비스 질 향상 등의 문제가 지적되어 왔다. 본 논문에서는 데이케어센터를 지역을 중심으로 접근하면서 그 발전방향을 논의하였다. 또한 전문가심층면접분석을 통해서 데이케어 센터의 차후 비전을 제시하였다. 심층분석 결과로는 데이케어센터에서 제공하는 건강케어 프로그램은 지역사회의 문 제 및 특성을 반영하여야 하고, 사용자 중심이어야 하며 지역통합적 방식을 취해야 함이 제시되었다.
\end{abstract}

Key Words : Long-term care insurance, adult day care center, health program, senior user program, community care

\section{Introduction}

Recent low fertility and increasing elderly population has led Korea into aged society rapidly. Elderly population reaches $11 \%$ in 2010 and expected to be up to $20 \%$ in $2020[1]$. While young population is decreasing, life expectancy is incrementally growing. Aging population is not a sudden new phenomenon in our society, as it covers quite a few countries in the world. It is the right time to consider carefully about elderly issues, because it will bring some negative effects to the whole society[2]. Demographic change comes with other social problems such as smaller family size, women's social participation and change of family value and community network. The improvement of medical technology allows elderly people with chronic illness and dysfunction live longer than before, too. Therefore social responsibility for elderly care should be the inevitable choice of the government.

After introducing long-term care insurance in Korea since 2008, formal sector of elderly care has been expanded. With newly established national insurance, there have been also some changes in society: emergence of new job field which is aged care worker; flood of

This work was supported by Korea Research Foundation(NRF-2010-330-B00194)

*Corresponding Author : Jeong-Won Han(Catholic University of Pusan)

Tel: +82-51-510-0832 email: jhan@cup.ac.kr

Received January 28, $2014 \quad$ Revised March 5, 2014

Accepted March 6, 2014 
diverse institutions which are specialized hospital and facilities for frail elderly. Rapid ageing speed in Korea brought diverse institutions and programs which have never been existed before. Not only ageing speed is the main issue when we consider aged society in Korea. The rapid increase of frail elderly, especially senior citizens with dementia are in the midst of ageing issues. $74 \%$ of elderly residents in the current nursing facilities are reported to have dementia[3]. With deterioration of physical and mental function, people with dementia have few choices for residence.

Daycare center is one of the facilities that provide adult day services (ADS). Being different of nursing home and residential home, daycare center is the one of home-based services, which users can still stay at home. This sort of institution have several merits: first of all, it does not exclude family and friends in elderly care, as users can stay in the familiar environment; second, as mental stability is important in later life, comfortable environment will help user's holistic health; third, user's normal life can stay without sudden change, so users can accept effective services without much resistance. However, considering the increasing nursing home and residential home, daycare center seems not play the proper role in the community yet. Care in the community is important to protect people's independent life with dignity; therefore, the role of ADS should be noticed more seriously.

Institutionalization is the decreasing trend in the developed welfare states, as the user's independence and rights of choice are respected in deciding user's own older life. In elderly care, the role of community is considered with importance. Regarding expense and resources in long-term institution, community care is more effective in many ways. In Korea, after long-term care insurance, small-size group home was also introduced and the old categories of elderly facilities are clarified [4].

By reflecting the trend of deinstitutionalization, activating daycare center is the key point of reducing the tax-expense in elderly care and creating communicative social care regarding generation and community. Therefore, in this paper, the role of day care center and the way of new health care program for seniors would be suggested, considering the basic medical care and welfare needs. Care program which only accept medical part or welfare part selectively would not be ideal for integrative care for seniors, so new expanded perspective is definitely needed in the aged society.

\section{Long-term care insurance and adult day services}

ADS in Korea has been introduced in 1992, and now expanded to 850 sites nationwide. The rapid increasing of ADS is due to the introduction of long-term care insurance, which is the social insurance system that provides long-term care benefit to the elderly who have difficulty taking care of themselves for a period of at least 6 months due to old age or geriatric disease. It supports them in their physical activities or housework based on the principle of social solidarity[5]. Being different from the previous elderly benefit system, long-term care insurance covers elderly people aged over 65, especially seniors with senile diseases such as dementia. This insurance means something in socialization of care responsibility, which takes burden from family to the state. Regarding aging situation in Korea, the social need for home-based day care services will be increasing[6].

To take care of frail elderly people, ADS includes both health and welfare services; it means elderly people who live in the community can use services, keeping normal life. Deinstitutionalization has strong impact to promote ADS where senior users' needs are fulfilled through diverse program. In Korea, people's consciousness about elderly facilities has been negative in spite of increasing numbers. Elderly people are reluctant to choose nursing home or special hospitals for their later life. Even though many of senior citizens want to stay at their familiar environment, several reasons such as health problem and obstacles of independent life drive them to institution.

Therefore, ADS emerges as the key to solve this gap between reality and negative images of elderly institution. The function of ADS is divided into three sections: first, providing rehabilitation services to restore physical empowerment; second, supporting senior citizens to keep their favorite leisure and socialization activities; third, preventing serious diseases through constant health check and health-promoting program[7]. Furthermore, ADS can 
play an important role to connect lonely elderly people with community, which will decrease serious violation against elderly people such as suicide and lone death.

The importance of ADS is increasing in people's consciousness. Japan which is highly aged society, for example, day care center for elderly people is important facility especially to prevent serious disease of dementia. ADS in Japan is the place where people communicate, help and rehabilitate each other. Local authority in Japan will try to improve the quality of services in ADS, supporting material resources and social network[8]. In Korea, after settlement of long term care insurance, day care center is expanding fast; however, in terms of diversity and quality of services, still tasks unsolved remain strongly.

[Table 1] Home-based Services for Seniors

\begin{tabular}{c|c}
\hline Services & Contents \\
\hline Visiting Care Services & $\begin{array}{c}\text { Providing visiting } \\
\text { services to users with } \\
\text { physical and mental } \\
\text { handicap }\end{array}$ \\
\hline Daycare Services & $\begin{array}{c}\text { Providing services in the } \\
\text { institution during day time } \\
\text { to adults } \\
\text { who need special care }\end{array}$ \\
\hline Short-term Services & $\begin{array}{c}\text { Providing short-term } \\
\text { living condition for users } \\
\text { who cannot have } \\
\text { services from family }\end{array}$ \\
\hline Visiting Bath Service & $\begin{array}{c}\text { Visiting users at home } \\
\text { with bathing equipment }\end{array}$ \\
\hline Support Services & $\begin{array}{c}\text { Providing counseling, } \\
\text { family education, } \\
\text { convenience services } \\
\end{array}$ \\
& to older adults at home \\
\hline
\end{tabular}

Now, there are 5 sorts of home-based services in Korea. Even though people say that daycare center is for older adults, in reality, frail elderly people often use these services. In other words, healthy adults have meek access opportunity and there are few programs for relatively healthy adults. Daycare center provide diverse support services to help elderly people with difficulties in daily life. Even though they are rated to use these services, some elderly people do not want to use day care center because they would like to stay at home. Visiting care services are provided for isolated elderly people, however, this service has limitation to provide holistic care for users, as service quality totally depends on visiting carer. In addition, isolation and depression of users cannot be solved with visiting care services.

Amongst these five services, daycare services have daily program for users who are mainly elderly people with some difficulties in daily life. Daycare centers are planned to provide a co-ordinated program of professional and compassionate day care services for the elderly in a community-based group setting. However, many researches[9-11] point out the difficult situation of running proper program to users in daycare centers. Even though these services are designed to improve or maintain quality of life, to promote independence, facilitate friendships, and provide social contact and stimuli, there is little strong impact in reality.

Therefore, development of proper program which consider users' need and desire should be established. Proper program means that it should consider age, physical and mental condition, family's needs, environment and user's decision power. Day care center can provide total care for users, keeping normal life in familiar environment. It reduces depression and isolation which happen when elderly people feel devastated outside home.

\section{Research method}

To explore the proper role of day care center, Delphi method is used in the paper. 10 senior workers are interviewed using in-depth interview skills. Interview contents are shown as [Table 2] which are facilities, specialty, human resources, service and satisfaction, tailored service, insurance, network and size.

Interview categories are selected through the frontier survey research, which was based on the regulation published by Ministry of Health and Welfare. Each section has detailed and specific questions. In-depth interviews with 10 experts who have been working in the field of ADS at least over 5 years were carried out in Seoul and Busan City, Korea. Each interview was carried out for about 2 hours and facility observation was followed. All interviews are note-taken and prescribed afterwards, analyzed by contents and question orders. 


\section{Interview Analysis}

Interview results are shown in Table 2. To find out new visions of stabilizing daycare center in the community, as a main networking port of social care, experts point out that the established program cannot afford to offer many choices to users and families. The main reasons are the lack of human resources and financial limitation, which lead to the shortage of program that keep users participating society and their own community.

First of all, keeping facilities safe and comfortable is the basic task for operators. Regulation on the elderly facilities is more and more strengthen yearly, and remodeling fee and restoration fee are quite limited. Facilities are getting older and some users with violent tendency often make faults in the important equipment, therefore keeping expense is quite high. Most operators try to keep ADS as homely environment to make users feel comfortable and safe. According to the regulation, safety rule is quite strong so it is another stress on the officers.

Specialty is linked with main program in the center. Self-choice policy was adapted to a few center, however, most of center have the established and scheduled program weekly. Some of day care center in Seoul has a number of common special programs such as horticultural therapy program. Horticultural therapy is currently run in several hospitals, organization, and welfare facilities, too. This program promotes users' health and prevents the chronic disease to be worsened, and some researches prove that growing plants are effective for dementia treatment[12]. A few therapies such as music therapy, drama therapy, art therapy are also favored by officers, however, the cost of materials are not affordable[13].

Human resources are the main problem to solve, when we regard aged society. Long-term care insurance services also concern about the way of fostering care workers. In reality, ADS regulation states that there must be one care worker per seven elderly people in the facility. However, the regulation of one care worker per seven elderly people does not guarantee the quality of service. Japan, for example, has the problem of providing a nice care worker. In Japan, the number of care workers nearly doubled from one million in 2000 to two millions in 2005. Most of care workers were dissatisfied with pay and more than 30 per cent of them were unhappy with working condition[14]. Care workers in Korea have the similar problem in the field. Even though their legal condition is regulated in the related law, the working condition with frail elderly people is not easy at all, and most of them have quite amount of stress and fatigue. Senior workers have problem of dealing with care workers' stress as well as documentary work and often inspection. Unstable employment and improvement of care worker's working condition is to be solved soon for the better quality of services.

[Table 2] Interview Composition and Analysis

\begin{tabular}{|c|c|}
\hline $\begin{array}{l}\text { Cate- } \\
\text { gories }\end{array}$ & Contents \\
\hline $\begin{array}{c}\text { Facili-ti } \\
\text { es }\end{array}$ & $\begin{array}{l}\text {-Demand of comfortable environment with new } \\
\text { equipment } \\
\text {-Safety are essential } \\
\text {-Remodeling fee need to be funded }\end{array}$ \\
\hline $\begin{array}{l}\text { Spe- } \\
\text { cialty }\end{array}$ & $\begin{array}{l}\text {-Self empowerment is essential } \\
\text {-Sustainable service } \\
\text {-Service manual } \\
\text {-Special program needs to be developed such } \\
\text { as music therapy, drama therapy and } \\
\text { horticultural therapy } \\
\text {-Regular volunteering }\end{array}$ \\
\hline $\begin{array}{l}\text { Hu- } \\
\text { man } \\
\text { Reso-ur } \\
\text { ces }\end{array}$ & $\begin{array}{l}\text {-Improvement of carers' welfare condition and } \\
\text { payment } \\
\text {-Unstable employment status leads transition of } \\
\text { employers } \\
\text {-Personal demand is not often accepted }\end{array}$ \\
\hline $\begin{array}{l}\text { Service } \\
\text { and } \\
\text { Satisfa- } \\
\text { ction }\end{array}$ & $\begin{array}{l}\text {-User's satisfaction is related with family's } \\
\text { opinion } \\
\text {-Daily services are not user-fitted } \\
\text {-Most services are focused on function- } \\
\text { rehabilitation, health management, social skill } \\
\text { development and psychological recovery }\end{array}$ \\
\hline $\begin{array}{l}\text { Tailor-e } \\
\text { d } \\
\text { Service }\end{array}$ & $\begin{array}{l}\text {-Respect of user's decision and choice } \\
\text {-Safe and stable service } \\
\text {-User's tool } \\
\text {-Inter-generational program }\end{array}$ \\
\hline $\begin{array}{l}\text { Insu- } \\
\text { rance }\end{array}$ & $\begin{array}{l}\text {-Long term insurance and stratification need to } \\
\text { be specified } \\
\text {-More object stratification tool should be } \\
\text { developed } \\
\text {-Emergence of blind spot }\end{array}$ \\
\hline $\begin{array}{l}\text { Net- } \\
\text { work }\end{array}$ & $\begin{array}{l}\text {-Necessity of daycare center in the community } \\
\text { are increasing } \\
\text {-Network with other institution in the } \\
\text { community are increasing } \\
\text {-Family/neighborhood networking is more } \\
\text { important }\end{array}$ \\
\hline
\end{tabular}


\begin{tabular}{l|l} 
Size & -Both large size and small size are needed
\end{tabular} -Large size center have benefits of high-quality human resources and diverse services -Small size center have familiar environment of home, providing tailored services to each users

-Need of having transitional form from daycare center to nursing home

Services provided by the center are rather limited and tightly scheduled. Most interviewees agree that there should be more flexible schedule regarding users' condition, yet there is a gap between reality and ideal. Sometimes user's family demand a special kind of services, but it is really hard to accept their asking all the time. Most services are centered on function rehabilitation and health management. Occupation therapy is welcomed by physically frail elderly people in terms of rehabilitation. There are some social kill development and psychological recovery program, however, this sort of services is to be supported and sponsored in the future. Expert and reliable volunteers are needed in the filed for the activation of these special services. User's satisfaction is closely related with family's satisfaction. User with family is more positive and active in participating in the diverse program, while lone elderly person is more negative and calm in the program. Family means the supportive welfare provider to older people; therefore, ADS should try to develop the expanded program to include family in user's life more. In fact, in the idea of welfare mix, providers of welfare looks at various other diverse entries; and amongst them, family plays the main key role[15].

Respecting the individual's choice and own life, the necessity of each tailored service is increasing. ADS's next task will be the development of the effective individualized tailored program, concerning the individual's own health, mental, and familial condition. For better rehabilitation, elderly people need tailored services as well. User-oriented services need enough human resources, knowledge-based practical program skill, and affordable budget condition. Collecting sponsors and resources would be another capacity of ADS to accomplish the settlement of tailored services for customers.

Interviewees also point out the problem occurred in the process of insurance services. Stratification details are not clear enough to define to the right beneficiaries; so sometimes the person who needs the insurance would be dropped or skipped. Actually, long-term care insurance is concerned about the way of finance sourcing method, infrastructure construction and fairly not enough clarification of detail contents[16]. Furthermore, blind spot exists in the insurance regulation. Disabled people are excluded in this insurance benefit, even though they need more social support than any other people in the society. Most chronic disease is not accepted in this insurance, too. The most serious disease like cancer and injury by accident are excluded by the insurance regulation. More objective, generous and clear stratification tool should be established soon.

In terms of network, daycare center plays a good role to connect community with elderly people and family. In other way, daycare center also need social networking strongly in order to do its function fully. Nowadays, social network for child care is popular, and people's consciousness for protecting child from any social risk is common. Social responsibility for elderly care should be developed further in the future. Networking, in this perspective, has many meanings; networking between welfare providers, networking between institutions, and networking with many subjects in the community. Networking itself has power to recruit proper human resources and provide high quality of services. Also, considering low budget situation in ADS, networking leads a good amount of sponsoring.

Last, size of ADS is discussed. Large size of ADS where over 50 users are in have benefits of diverse service and relatively nicer financial condition. Many human resources can provide diverse services which are fit to users. Small size ADS can provide more familiar and homely environment to users but has limitation of space, services, and provision of care workers. ADS where about 30 people use hardly provide high skilled services such as rehabilitation therapy and function restoration[17]. Like other welfare organization, ADS needs to be considered on the expanded line of aged care such as linkage of nursing home. ADS users may soon to be nursing home users; and when this case happens, the connection of similar-environment facilities are very helpful to provide familiar services to older people. 


\section{Conclusion}

Aged society means that over $14 \%$ of elderly population is over aged 65 . Due to low fertility rate which is as lower as 1.4 in 2012, high cost of private education and child care, women's active social participation and change of social structure and family values, Korea is driving towards aged society very fast. Realizing social responsibility and co-operative solidarity, the government launched long-term care insurance for elderly people in 2008; and it has been activated for 5 years so far. The emergence of long-term insurance is something that deliver the state's will to take care burden from family to society, it also brought social dispute such as blind spot, unclear stratification and unfair manipulation.

ADS is one of facilities which is activated after long-term insurance. Unlike nursing home, hospital and residential home for older people, ADS is located in the community and elderly people can use the center while they still stay with their family. Considering frail elderly people do not want sudden change of environment, ADS is the ideal space for weak older people who try to restore their physical and mental condition, supporting by family and community. Therefore, to carry out community care and family-friendly elderly care, ADS would be a center that plays an important role to connect community with elderly care. This kind of center does not exclude family, relatives and friends; in contrast, it includes the entire community member to elderly care project. Therefore, with importance of ADS, this paper analyzed interview result with 10 expertises who have been working in ADS over 5 years as senior worker.

There are need of developing in the section of facilities, specialty, human resources, service and satisfaction, tailored service, insurance, network and size. Also new health care program specialized in ADS should be developed soon. Some users are stick to the traditional notion of "no one here gets out alive"[18]. Providing proper rehabilitation program and total care project, more healthy life would be guaranteed. With expanding of the term of 'normalization' and 'deinstitutionalization', user's own decision power in their life is getting emphasized. Therefore, with strength of program and sustainable service quality is needed to help older people's independent and high standard of older life.
The new way of ADS would be first, moved from manager-oriented to user-oriented. Few managers ask what users want, and reflect to the running program. Universal and monotonous schedule without consideration of user's desire does not have an effect to real rehabilitation of older life. When user's own decision power is respected, and when human resources are enough to provide high quality of services, and when financial support is affordable for proper project, user-oriented service mind and facility running rule would be settled safely.

Second, Holistic care program which treat both welfare and medical sector should be developed. Expertise in both sector such as social worker and nurses have to do cooperative work in the field of elderly care. As interviewees suggested importantly, care worker need to participate in elderly care more positively with special skills and knowledge. With introduction of long-term care insurance, many number of care worker have been educated, but in reality, their activation in the labor market is not as much as expected before due to unstable working condition and low income. Care worker's role should be more professionalized in the near future in order to guarantee high quality of services. There should be more welfare benefit for care worker, so that they can escape from low-income and low-confidence and low job-consciousness.

Third, Community-based program would be more effective to induce user's participation into the society. As interviewees state, inter-generational communication is also very important to encourage user's consciousness of self-respect and belongings. As welfare providers, each sector of welfare mix which are state, volunteers, market, family and community need to cooperate for fulfillment of elderly care.

Lastly, ADS's role is to be more expanded and strengthened in the society. Long-term facilities and hospitals are not the only solution for frail elderly people with dementia and chronic illness. Home-based services and community-based facilities are more activated, as the social responsibility of elderly care is ours. Elderly care is not minority's issues, as everybody is getting old and be an old person sometimes in the stage of life. Independent and healthy older life is helped by the whole community; and ADS is to be a center that fulfill that 
purpose.

\section{References}

[1] National Statistics Office. PopulationSurvey. Printed on 11. 01. 2013

[2] Seoul development Institute. Seoul Super Aged Society; how would respond-strategies for the negative impact. SDI Policy Report vol.80. no.2. 2011.

[3] H. J. Kim. Research on Development of Care Services in Nursing Facility. Mok Won Univ. Unpublished MAthesis. 2003.

[4] M. J. Chun. Research on ADS Module, KwanDong Univ. Unpublished $\mathrm{PhD}$ thesis 2011.

[5] National Health Insurance Service, Long-term Care Insurance .Printedon 10. 15. 2013.

[6] S.Y. Lee. And J. Kim. "Study on Community Care System for Older People in Japan and the UK" Journal of Regional Studies. vol. 18, no. 1, pp. 127-149. 2010.

[7] Y. K. Koh. Elderly People ,SocialWorker's Organization Press. 1997.

[8] M. K. Cho. "Japanese Adult Day Care Center" Bok Ji Dong hyang, Seoul City, 2010.

[9] J. H. Chang, Introduction of Long-term Insurance. DelSam. 2010.

[10] K. S. Koh, Activating Adult Day care Center: Focusing on Service Provision, DongKuk Univ. Unpublished MAthesis. 2002.

[11] K. T. Lee, Situation of ADS and Satisfaction, Kong Ju Univ. Unpublished MA thesis. 2006.

[12] B .H. Kwack. Newly Developing Field of Horticulture and Horticultural Science. Journal of Korean Society of Horticultural Science,.vol.2, no. 1, pp.4-8. 1984.

[13] S.D. Lee, Y.J. Chang \& C.H. Pak. "The Recognition and the Actual Conditions of Horticultural Therapy Program at Seoul Type Day-Care Centers" Journal of Korean Plants Environment. vol.15, no. 2, pp.79-84. 2012.

[14] M. Nishikawa. "(Re)defining Care Workers as Knowledge Workers" Gender, Work and Organization. vol.18, no. 1, pp.113-136. 2011.

DOI: http://dx.doi.org/10.1111/j.1468-0432.2010.00537.x

[15] E. Ochiai. "Care Diamonds and Welfare Regimes in East and South-East Asian Societies: Bridging Family and Welfare Sociology" International Journal of Japanese Sociology. vol.18. pp.60-78. 2009.

DOI: http://dx.doi.org/10.1111/j.1475-6781.2009.01117.x
[16] J. K. Koh. "Problems and Improvement of Long-term Insurance Law" Dongah Law. vol. 57, pp.289-317. 2012.

[17] D. Sunwoo. "Policy Issues for Improvement of Beneficiary System in Long-Term Care Insurance for the Elderly" Health and Welfare Forum .vol. 3, pp.50-58. 2012.

[18] N. Fields, A. Anderson, \& D. Holly, "Ready or Not: Transitioning from Institutional Care to Community Care", Journal of Housing for the Elderly, vol. 25, pp.3-17. 2011.

DOI: http://dx.doi.org/10.1080/02763893.2011.545330

Jeong-Won Han

[Regular member]

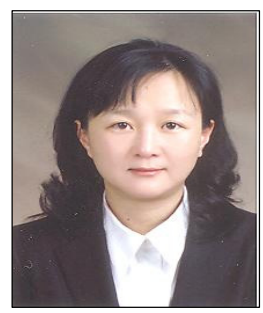

- Feb. 1991 : Sogang Univ., BA

- Feb. 1993 : Sogang Univ., MA

- July. 2003 : Univ. of Sussex, $\mathrm{PhD}$

- Mar. $2009 \sim$ current : Catholic Univ. of Pusan., Dept. of Aging and Social Work, Professor

$<$ Research Interests $>$

Elderly Welfare, Social Policy, Gender Policy 